\title{
Demand Analysis for Consumer Preference of Cowpea Attributes In Niger State, Nigeria: A Hedonic Approach
}

\author{
${ }^{1 *}$ Ibrahim, F.D.; ${ }^{1}$ Nmadu, J.N.; ${ }^{1}$ Baba, K.M.; ${ }^{1}$ Gana, A.S. ${ }^{2}$ Danbaba, N. and \\ ${ }^{2}$ Ibrahim, P.A. \\ ${ }^{I}$ Department of Agricultural Economics and Extension Technology, School of Agriculture and Agricultural \\ Technology, Federal University of Technology Minna Niger State, Nigeria \\ ${ }^{2}$ National Cereals Research Institute, Badeggi, Bida Niger State
}

\begin{abstract}
The study investigated the Demand analysis for consumer preference of cowpea attributes in Niger State, Nigeria. The study employed a multistage stratified and systematic random sampling to select markets and respondents for the study. Markets selected were Kontagora market in (production region),Sabon Wuse market in Tafa (transitory region) and Minna market in (consumption region). Time series data for the price/quality information were obtained from respondents in these markets. Cowpea samples were purchased every month from five (5) systematically, randomly selected retailers in each market for 12 months. Data were analyzed using the Hedonic model. Findings from the study revealed that consumers were willing to pay a premium for additional unit of grain weight at $\$ 0.96$; rough testa texture at $\$ 40.64$ and white eye color at $\$ 21.42$ and $\$ 11.90$ from different markets estimated. On the other hand consumers were ready to discount prices for bruchid/insect hole damage at $\$ 1.00$, white testa color in Kontagora market at $\$ 17.73$; 40.90 in Sabon Wuse market and $\$ 46.66$ in Minna market. Recommendations from this study included the need for the provision of better storage media such as the triple hermatic storage sacks, to market participants to reduce the number of insect infested beans. Most preferred qualities of cowpea such as grain weight, rough testa texture and white eye color should be disseminated to breeders to come up with varieties encompassing these qualities.

Key words: Demand, Consumer preference, Hedonic model and cowpea attributes
\end{abstract}

\section{Introduction}

Demand theory has traditionally been based on the fundamental precept that a product or service generates utility. Hence, utility theory has been used to analyze consumer choice of a good or a service based on price and a budget constraint. In the case of food products, the price a consumer is willing to pay maybe a function of the marginal implicit prices that an individual is willing to pay for each nutrient (Faye, 2005).

According to Lancaster (1966), utility is derived from the properties or characteristics of goods. He suggested that consumption was an activity for which goods and services singly or in combination, are inputs and a collection of the characteristics is the output. Lancaster's theory of demand for characteristics plays a crucial role and lays the necessary conceptual framework in the development of modern hedonic demand analysis. Applying the Lancaster's theory that consumers purchase goods because of the utility derived from their characteristics or attributes, economists have applied Lancaster's theory to agricultural products. Through these they have also developed hedonic approaches for exploring price-quality relationships to estimate the implicit values of product characteristics (Ladd and Martin 1976; Ladd and Suvannut 1976; and Rosen 1974). The underlying assumption in the development of the hedonic model is that products can be distinguished simply and uniquely by their characteristics. Thus demand for various desired characteristics can be derived from consumer willingness to pay for a product. As a result, marginal or implicit values can be estimated for each attribute at the observed purchase price, which is linked to the number of characteristics contained in the goods purchased.

Accordingly Huang and Lin (2007) stated that the hedonic approach is a disaggregation of commodities into characteristics and the estimation of implicit prices for units of the characteristics. Statistical measurement of the relationship between prices paid by consumers for a product and the quality mixes contained in that product can be used to interpret these marginal values in monetary terms.

Nnanyelugo et al; (1985) and Mcwatters et al; (1990), reported that Nigeria was the largest consumer of cowpea in the world. Ayinde et al; (2002) reiterated that cowpea as a food source provides the cheapest protein supplement to the urban and rural poor in Nigeria. The eating habits of most rural and urban poor thus revolves round cowpea consumption in many forms either through direct cooking of cowpeas, processing into bean cakes, bean pudding, dumplings, components of other meals such as in cowpea soups, rice and beans etc. The versatility of cowpea in this respect makes it a component of the food consumed in many households in Nigeria (Ayinde, 2005). 
Inspite of the prevailing level of consumption of cowpea and its versatility, information on cowpea attributes/characteristics most preferred by these consumers is not available from earlier research works in the study area. Knowledge of quality factors that commands a price premium or provokes a price discount are also presently lacking in the study area. The main objective of the study is to determine the effect of cowpea attributes on price through a price-quality relationship approach.

\section{Materials and Methods}

This study was conducted in Niger State of Nigeria. The State's capital is minna and it comprises of twenty five (25) local government areas grouped into three agricultural zones: A, B and C. Niger State falls within latitudes $6^{\circ} 30^{\prime}$ to $11^{\circ} 20^{\prime}$ North and longitude $2^{\circ} 30^{\prime}$ to $10^{\circ} 30^{\prime}$ East. The State is located in the Southern Guinea Savanna ecological region of Nigeria. The study area experiences two distinct climatic seasons in a year, the (rainy and dry seasons) respectively. Rainfall is steady and is evenly distributed falling usually between May and November, varying from $1,100 \mathrm{~mm}$ in the North to $1,600 \mathrm{~mm}$ in the South, peaking in August.. The dry season commences in November and the relative humidity could be as low as $14 \%-40 \%$ between December and January and as high as $66 \%-88 \%$ in the rainy season. The maximum temperature does not exceed $37^{\circ} \mathrm{C}$, and is recorded between March and June; it covers a land area of $86,000 \mathrm{~km}^{2}$ which is about 10 percent of the total land area of the country (Niger State Agricultural Development Project, 2002). A multistage stratified and systematic random sampling technique was employed. Firstly, the markets were stratified on the basis of production regions, transitory and consumption regions. Secondly, one (1) market each was randomly selected from the production zone, the transitory zone and the consumption zone giving a total of three (3) markets. Data were collected from retailers, in the following three markets, modern market in Kontagora (production region), Central market in Minna (consumption region) and Sabon-wuse market in Tafa (Transitory region). The markets were selected according to the volume of cowpea sales, proximity to each other and size of consumers in such locations. Five (5) retailers each were systematically selected from each market every month, for the purchase of cowpea samples. A randomly chosen seller was picked first; every $5^{\text {th }}$ seller was then selected, from whom a sample of cowpea was purchased. This was carried out for 12 months i.e. (One year), giving a total sample size of 180 retailers.

For each sample of cowpea bought, data were recorded on the following variables following Faye, 2006 and Musa, 2003;

$1 \quad$ Market price per unit of cowpea bought (in Naira)

2 Testa texture (smooth or rough)

3. Testa colour (white or brown)

4. $\quad$ Eye colour (white or black)

5. Weight of 100 grains of cowpea (in grams)

6. Number of bruchid holes (insect holes), broken and discoloured (absolute).

7. Grain size (millimeters)

8. $\quad$ Selling period (month)

9. $\quad$ Sucrose level (in \%)

10. Cooking time (minutes).

Hedonic model for cowpea characteristics adopted in this study is specified following Ladd and Savannut (1976):

$\mathrm{P}_{\mathrm{C}}=\sum_{j=1}^{m} X c j+\beta c j+e$

Where

$\mathrm{P}_{\mathrm{c}}=$ Price of cowpeas in $\mathrm{Ng}$.

$X c j=$ Quality of cowpea grain characteristics $\mathrm{j}$ (such as grain size, testa colour, eye colour, number of bruchid holes/ 100 grains, testa texture etc).

$\beta c j=$ Implicit value of characteristics $\mathrm{j}$.

$e=$ Random error

From the general function, the regression model to be estimated is specified thus:

$P_{i t=\alpha+\sum \gamma i r+Y i r t+\sum \Psi_{i k} \mathrm{M} i k t+\sum \beta i j \mathrm{X} i j t+E i t}$

$P_{i t=}$ Price of cowpea in $\mathrm{A} / \mathrm{kg}$

$\propto=$ Constant term

$Y_{\text {irt }}=$ Yearly dummy $(\mathrm{r}=1$ for year, 2011 and 0 otherwise $)$

$M_{i k t}=$ Monthly dummy $(\mathrm{k}=1,2, \ldots \ldots \ldots . .12)$ to account for the effect of time on price variability

$X_{i j t}=$ Cowpea characteristics $(\mathrm{j}=1,2,3, \ldots . \mathrm{J})$, Cowpea grain size, colour, texture, eye colour etc

$\beta, \gamma$ and $\Psi=$ Parameters to be estimated.

$E=$ Stochastic term 


\section{Decision:}

If null hypothesis of no contemporaneous correlation is rejected then demand models for the different markets are estimated using the Seemingly Unrelated Regressions (SUR) to account for correlation between disturbances from different equations.

Seemingly Unrelated Regression (SUR) is denoted by the following equations

$P_{M}=f(G w t, N H, S T, S C, E C, G, S P$ and GS $)$....

$P_{C}=f(G w t, N H, S T, S C, E C, G, S P$ and GS $)$

$P_{S}=f(G w t, N H, S T, S C, E C, S G, S P$ and GS $)$.

Where:

$\mathrm{P}_{\mathrm{M}}=$ Price of cowpea in modern market (Kontagora) in $\mathrm{N} / \mathrm{kg}$, dependent variable.

$\mathrm{P}_{\mathrm{C}}=$ Price of cowpea in Central market (Minna) in $\mathrm{N} / \mathrm{kg}$, dependent variable.

$\mathrm{P}_{\mathrm{S}}=$ Price of cowpea in Sabonwuse market (Tafa) in $\$ / \mathrm{kg}$, dependent variable. .

$\mathrm{Gwt}=$ Grain weight (average weight of 100 grains in the three different markets under study) in grams .

$\mathrm{NH}=$ Number of bruchid holes per 100 grains

$\mathrm{ST}=\mathrm{Skin} /$ testa texture (dummy variable, 1 if rough, 0 otherwise).

$\mathrm{SC}=\mathrm{Skin} /$ testa colour (dummy variable, 1 if white, 0 otherwise).

$\mathrm{EC}=$ Eye colour (dummy variable, 1 if black, 0 otherwise).

$\mathrm{G}=$ Gender of seller (dummy variable, 1 if male, 0 otherwise).

$\mathrm{SP}=$ monthly dummy $(1,2,3 \ldots$ months. To account for time in price variability).

$\mathrm{GS}=$ Grain size (dummy variable, 1 if big, 0 otherwise).

\section{Data entry and measurements}

For the measurement of Grain weight, (100 grain weight) of cowpea, the average weights of 100 grains were recorded. 100 grains of each cowpea sample were measured in triplicates with the aid of an electronic balance. For grain size ten grains were selected, their principal dimensions of major length (L1), minor length (L2) and intermediate length (L3), were measured with a vernier caliper. The average length multiplied by width was recorded in millimeters. Testa colour data entry was accomplished by visual inspection. In the case of testa texture, both visual observation and finger touch was used to establish texture identity. Two textural classifications namely rough and smooth textured were recorded. Visual observation was employed to identify cowpea eye colour. For the measurement of damage level / number of bruchid holes and discoloured grains, visual observation and counting of grains with holes in them (from 100 grains) was employed.

\section{Results and Discussion}

Table 1: Summary Statistics for Prices (P), Weight (W100g), Insect Damage (Nh), Cooking time (Ct), Grain Size (Gsize) and Sucrose Content (Sc) of Cowpea

\begin{tabular}{|c|c|c|c|c|}
\hline Item & $\mathrm{N}=60$ & Kontagora & Sabon-Wuse & Minna \\
\hline \multirow{4}{*}{$\begin{array}{l}\text { Price }(\mathrm{P}) \\
(\mathrm{N}) / \mathrm{Kg}\end{array}$} & Mean & 127.70 & 149.50 & 166.86 \\
\hline & St. Dev & 34.70 & 54.72 & 54.07 \\
\hline & Minimum & 80 & 90 & 93.75 \\
\hline & Max & 200 & 321.47 & 312.5 \\
\hline \multirow{4}{*}{$\begin{array}{l}\text { Weight } \\
\text { W100 } \\
\text { (grams) }\end{array}$} & Mean & 20.92 & 22.28 & 22.57 \\
\hline & St. Dev & 6.52 & 4.66 & 6.19 \\
\hline & Minimum & 7.13 & 9.27 & 8.4 \\
\hline & Max & 35.84 & 33.96 & 40.95 \\
\hline \multirow[t]{4}{*}{ Insect Damage (Nh) } & Mean & 12.93 & 11.53 & 13.85 \\
\hline & St. Dev & 8.42 & 7.13 & 6.23 \\
\hline & Minimum & 2 & 2 & 6 \\
\hline & Max & 37 & 44 & 32 \\
\hline \multirow{4}{*}{$\begin{array}{l}\text { Cooking Time (CT) } \\
\text { (Minutes) }\end{array}$} & Mean & 17.90 & 18.33 & 18.11 \\
\hline & St. Dev & 1.91 & 2.20 & 1.66 \\
\hline & Minimum & 15 & 15 & 14.67 \\
\hline & Max & 26 & 26.33 & 23.33 \\
\hline \multirow{2}{*}{$\begin{array}{l}\text { Grain Size } \\
\text { (Gsize) }\end{array}$} & Mean & 70.07 & 55.09 & 61.99 \\
\hline & St. Dev & 32.49 & 38.58 & 38.14 \\
\hline
\end{tabular}




\begin{tabular}{llccc} 
& Minimum & 0.53 & 0.33 & 0.16 \\
& Max & 141.79 & 111.25 & 120.68 \\
$\begin{array}{l}\text { Sucrose Content (SC) } \\
(\%)\end{array}$ & Mean & 11.005 & 15.64 & 12.88 \\
& St. Dev & 5.615 & 15.83 & 6.75 \\
& Minimum & 0.79 & 0.9 & 0.96 \\
& Max & 21.6 & 89.1 & 31.5 \\
\hline
\end{tabular}

Source: Field survey Data, 2013

From Table 1 mean prices from the markets studied indicated relatively large variations over time between Kontagora and Sabonwuse markets, but showed small differences between Sabonwuse and Minna markets. The mean prices also appeared to show similar trends indicative of the deviations. Such deviations evidenced from this analysis give more credence to the importance of the study of price/quality relationship.

The mean grain weight varied between 20.92 and 22.28 gms/ 100 grains. The heaviest grains were observed in Minna market (40.95). The grain weights across the markets show relatively uniform sizes between (33 and 40 gms) and this was also evidenced by the low standard deviations indicating small differences between markets. This study is in agreement with findings of Faye (2005) in which cowpea grain sizes in Senegalese markets ranged from 17-19 gm/100grains with low standard deviations across markets suggesting uniform grain weights.

Insect damage, consisting of grains with bruchid/insect holes, broken grain, and discoloured grains per 100 grains revealed very high values. The average number of bruchid holes $(\mathrm{NH})$ per 100 grains was between 11 and 13. The highest rates of insect damage were found in cowpea grains in Minna market, while Sabonwuse market had the least. This can probably be attributed to the improper storage practices carried out by the market participants. The other reason which could be adduced for this could be the attack by the legume pod borer (Maruca) on the cowpeas, when they were still in the field as reported by the sellers. The result here contradicts results of Faye (2005) and Musa (2003), where number of bruchid holes/damage was relatively low (between 69 holes/100grains).

The average cooking time for cowpea samples was between 17 and 18 minutes. This is the minimum cooking time. The proportion of the cooking time for cowpea grains from the three markets presented a uniform cooking time with Sabon Wuse market revealing the highest cooking time of 26 minutes 33 seconds.

The mean sucrose level among cowpeas across markets ranged from $11.00 \%$ and $15.6 \%$. It is evident from the result that the sweetest cowpea varieties were found at Sabon Wuse market followed by Minna market and Kontagora market. This result revealed that cowpeas in Nigeria have higher sucrose content as against those found in Senegal at sucrose content of $5.2 \%$ and $6.8 \%$.

Table 2: Regression results of Hedonic analysis

\begin{tabular}{|c|c|c|c|}
\hline VARIABLES & Kontagora Market & Sabon Wuse Market & Minna Market \\
\hline Constant & 191.10 & 271.24 & 282.23 \\
\hline & $(6.60)^{* * *}$ & $(6.10)^{* * *}$ & $(7.98) * * *$ \\
\hline Weight of 100grains & 0.27 & -0.19 & 0.96 \\
\hline & $(0.54)$ & $-(0.34)$ & $(2.21)^{* *}$ \\
\hline Number of holes & -0.33 & -1.00 & -0.09 \\
\hline & $-(0.87)$ & $-(2.17)^{* *}$ & $-(0.19)$ \\
\hline Testa colour & -17.73 & -40.90 & -46.06 \\
\hline & $-(2.54)^{* * *}$ & $-(6.51)^{* * *}$ & $-(8.12)^{* * *}$ \\
\hline Testa texture & Dropped & $\begin{array}{l}40.64 \\
(1.86)^{*}\end{array}$ & Dropped \\
\hline Eye colour & $\begin{array}{l}-16.45 \\
-(1.19)\end{array}$ & $\begin{array}{l}12.42 \\
(1.75)^{*}\end{array}$ & $\begin{array}{l}11.91 \\
(1.89)^{*}\end{array}$ \\
\hline Cooking time & $\begin{array}{l}0.16 \\
(0.12)\end{array}$ & $\begin{array}{l}1.15 \\
(0.71)\end{array}$ & $\begin{array}{l}-1.29 \\
-(0.84)\end{array}$ \\
\hline Grain size & $\begin{array}{l}-0.09 \\
-(1.00)\end{array}$ & $\begin{array}{l}-0.13 \\
-(1.63)\end{array}$ & $\begin{array}{l}0.05 \\
(0.92)\end{array}$ \\
\hline Sucrose level & $\begin{array}{l}-0.94 \\
-(1.19)\end{array}$ & $\begin{array}{l}-0.19 \\
-(0.97)\end{array}$ & $\begin{array}{l}0.79 \\
(1.49)\end{array}$ \\
\hline Jul & $\begin{array}{l}-18.32 \\
-(1.17)\end{array}$ & $\begin{array}{l}-22.21 \\
-(1.71)^{*}\end{array}$ & $\begin{array}{l}-17.06 \\
-(1.72)^{*}\end{array}$ \\
\hline Aug & $\begin{array}{l}0.70 \\
(0.04)\end{array}$ & $\begin{array}{l}-24.58 \\
-(1.69)^{*}\end{array}$ & Dropped \\
\hline Sep & $\begin{array}{l}-5.36 \\
-(0.28)\end{array}$ & $\begin{array}{l}-30.61 \\
-(2.07)^{* *}\end{array}$ & $\begin{array}{l}-5.74 \\
-(0.50)\end{array}$ \\
\hline Oct & Dropped & Dropped & $\begin{array}{l}-4.00 \\
-(0.31)\end{array}$ \\
\hline Nov & 5.54 & -16.48 & -6.35 \\
\hline
\end{tabular}




\begin{tabular}{|c|c|c|c|}
\hline & $(0.49)$ & $-(1.24)$ & $-(0.51)$ \\
\hline \multirow[t]{2}{*}{ Dec } & -16.92 & -27.98 & -11.11 \\
\hline & $-(1.35)$ & $-(1.89)^{*}$ & $-(0.78)$ \\
\hline \multirow[t]{2}{*}{ Jan } & -59.80 & -167.57 & -140.94 \\
\hline & $-(3.78) * * *$ & $-(17.13)^{* * *}$ & $-(13.63)^{* * *}$ \\
\hline \multirow[t]{2}{*}{ Feb } & -48.09 & -130.62 & -141.85 \\
\hline & $-(3.17) * * *$ & $-(12.82)^{* * *}$ & $-(14.42)^{* * *}$ \\
\hline \multirow[t]{2}{*}{ Mar } & Dropped & -113.77 & -103.30 \\
\hline & & $-(11.53)^{* * *}$ & $-(10.59)^{* * *}$ \\
\hline \multirow[t]{2}{*}{ Apr } & -27.03 & -119.23 & -99.55 \\
\hline & $-(2.18) * * *$ & $-(12.75)^{* * *}$ & $-(10.15)^{* * *}$ \\
\hline \multirow[t]{2}{*}{ May } & -4.94 & -88.17 & -55.45 \\
\hline & $-(0.41)$ & $-(9.63)^{* * *}$ & $-(5.56) * * *$ \\
\hline \multirow[t]{2}{*}{ Jun } & 20.68 & Dropped & Dropped \\
\hline & $(1.67)$ & & \\
\hline \multirow[t]{2}{*}{ Gender } & 0.16 & 7.74 & 9.55 \\
\hline & $(0.03)^{* * *}$ & $(1.28)$ & $(1.44)$ \\
\hline \multirow[t]{2}{*}{ Year (2011) } & -53.76 & -148.14 & -122.20 \\
\hline & $-(4.03) * * *$ & $-(11.20)^{* * *}$ & $-(8.83)^{* * *}$ \\
\hline Year (2012) & Dropped & Dropped & Dropped \\
\hline $\mathrm{R}^{2}$ & 0.83 & 0.95 & 0.94 \\
\hline Adj $R^{2}$ & 0.75 & 0.93 & 0.92 \\
\hline F-ratio & $10.64 * * *$ & $42.09 * * *$ & $38.97 * * *$ \\
\hline
\end{tabular}

Source: Field Survey Data, 2013

t-ratios in parenthesis are statistically significant at *** $1 \% ; * * 5 \%$ and $* 10 \%$

The results of the Hedonic model analysis are shown in Table 4.15. Estimated regression results reveal that the explanatory variables included in the model explain between $83 \%$ and $95 \%$ of price variability in the three markets studied.

In terms of grain weight (W100g), only the consumers in Minna market were willing to pay a premium. The results indicated that in Minna market, consumers are willing to pay up to $\$ 0.96$ for each additional gram of grain weight. This suggests that processors and final consumers are willing to pay a premium for a heavier grain weight, probably because it is easier to crush and yields larger amount of flour.

The impact of bruchid holes (Nh /100) on cowpea prices was only significant at Sabon-Wuse market. This was found to be statistically significant at $5 \%$ level, results further indicated that consumers discount price by $\$ 1.00$ for any additional bruchid hole. The result is somewhat surprising albeit, where apriori expectations are that consumers should discount price for more than just 1.00 on any additional bruchid hole, which was not the case. However, the survey reveals that cowpea retailers did not follow the practice of sorting, grading and standardization of the cowpeas before selling. Consumers were just meant to buy cowpeas without any alternatives of purchasing well graded and sorted cowpeas at different prices.

With regards to Testa colour (Tc), it was found to be significant at the $1 \%$ level in all three markets. The results indicated that consumers in the three markets studied were willing to discount prices for white testa colour at $\$ 17.73$ in Kontagora market; 40.90 in Sabon Wuse and $\$ 46.06$ in Minna market respectively.

On the impact of Testa texture (TT) on price, it was found to be significant at $10 \%$ level at only Sabon Wuse market. The results revealed that consumers in Sabon Wuse market were willing to pay a premium of $¥ 40.64$ for the rough testa texture. The testa texture was dropped at both Kontagora and Minna market as a result of multicollinearity. This was because; all the samples of cowpea purchased were of the rough testa texture. The rough textured cowpea in all the markets studied appears to be the more preferred by consumers. The reason for this may be connected with the cooking of rough texture cowpea by consumers, which has been reported to be much easier to cook than the smooth texture. (Faye, 2005).

The impact of eye colour $(\mathrm{Ec})$ was found to be significant at 10\% level at the Sabon Wuse and Minna markets. Results also showed that consumers were willing to pay premiums of 12.42 and $\$ 11.90$ for white eye colour in Sabonwuse and Minna markets respectively. The parameter of monthly dummies for almost all the markets indicated a negative and significant impact on cowpea prices. The months from January- May 2012 revealed negative coefficients which were, significant at the $1 \%$ level. The results imply a consistent seasonal price pattern.

Gender was found to be only significant in Kontagora market at $1 \%$ level. The survey results generally showed that most cowpea retailers in all the markets were male dominated. Regarding the yearly dummies on the impact of cowpea price, the year 2011 indicated negative coefficients and significant at $1 \%$ level. But the year 2012 was dropped as a result of the constant nature of prices.

\section{Conclusion}

From the price/ quality study investigated, it was concluded that consumers are ready to discount prices for attributes such as bruchid hole/ insect damage in beans and white testa colour in Kontagora, Sabon Wuse 
and Minna markets. On the other hand, consumers were willing to pay premiums on attributes on an additional unit of grain weight, rough testa texture and white eye colour at the estimates from the different markets.

\section{Recommendation}

1. Market participants can be educated on grading/ sorting of their cowpeas to command different prices for their products, hence introducing quality standards and creating competition amongst participants. This can be achieved through the public-private participation initiated by government on the dissemination of market information, following the current Agricultural Transformation Agenda (ATA) in the country.

2. The use of good storage medium such as the triple hermatic storage sacks would reduce the damage caused by insects/pests and post harvest loses. Applying the strategy of the Agricultural Transformation Agenda (ATA), the private sector can be encouraged to promote the storage of cowpea through investing in the production of the triple hermatic storage sacks with a view to making it affordable and accessible to market participants.

3. The most preferred quality attributes which command price premiums such as grain weight, rough testa texture and white eye colour should be communicated to breeders. This can be carried out by the government, through the market information dissemination strategy of the ATA. This is to enable breeders come up with varieties of cowpea encompassing all these attributes.

\section{References}

[1]. Ayinde, I.A., Afolami, C.A., Aromolaran, A.B., Vaughan, I.O. and Fanimo A.O. (2002): 'Intra- zonal poverty situation among farmers in Ogun State'. Moore Journal of Agricultural Research 3 (2): 306-312

[2]. Ayinde, I.A. (2005): Market dynamics for cowpeas: weight and measurement issues in kuto market, Abeokuta, Nigeria. Report submitted as part of the market study on: Building a food marketing policy evidence base in Nigeria.

[3]. Faye, M.D. (2005): Investigations of key aspects for the successful marketing of cowpeas in Senegal. Published Ph.D thesis Department of Agricultural Economics University Of the Free State Bloemfontein South Africa.

[4]. Faye, M., Jooste, M., Lowenberg-Deboer, J. and Fulton, J. (2006): Impact of sucrose contents and cooking time on cowpea prices in Senegal. South African Journal of Economic and Management Sciences 9 (2): 207-212.

[5]. Huang, C.L., and Lin, B. (2007): Consumer preferences and attitudes towards organically grown produce. Review Agricultural Economics 29 (4): 783-800. DOI: 10:1111/j.1467-9353.2007.00387

[6]. Lancaster, K. (1966): Change and innovation in the technology of consumption. American Economics Review 56: $132-157$.

[7]. Ladd, G. and Suvannunt, V. (1976): A model of consumer goods characteristics. American Journal of Agricultural Economics 58: 504-510.

[8]. Mcwatters, K.H., Pretty, J.N; and Conway, G.R. (1990): Appropriate Technology for cowpea preservation and processing, and a study of its socioeconomic impact on rural population in Nigeria. Pg 46-49 in 10 years of collaboration research on Beans and Cowpeas, CRSP. Michigan State University East Lausing, MI. USA.

[9]. Musa, S.A., (2003): Marketing of cowpea in Nigeria: Econometric studies of quality factors and market integration. Unpublished Ph.D thesis submitted to the agricultural economics and extension programme Abubakar Tafawa Balewa University Bauchi, Nigeria. 402pp.

[10]. Niger State Agricultural Development Project (NADP) 2002

[11]. Nnanyelugo, D.O; King, J., Ene-Obong, H.N., and Ngoddy, P.O (1985): Seasonal variations and the contribution of cowpea (Vigna Unguiculata) and other legumes to nutrient intakes in Anambra State Nigeria. Ecology of food and nutrition, 17:271-287.

[12]. Rosen, S. (1974): Hedonic prices and implicit markets: product differentiation in pure competition. Journal of Political Economics, 82: 34-55. 